that the evidence (upstanding granitic “tors") demands unglaciated, yet smooth and rounded summits up to altitudes of the order of $\mathrm{I} 100 \mathrm{~m}$., in spite of the very abundant glaciation below. Moreover, the slopes are such that one cannot imagine the ice standing still. In the previouslycited paper (195I) I have brought forward the evidence for a firn line at only about $130 \mathrm{~m}$. in north-western Scotland; whereas Linton's evidence would appear to demand a firn line not lower than $500 \mathrm{~m}$. on the eastern Cairngorms when glaciation was at its maximum. This may again throw light on the question of the amount of precipitation, and its eastward decrease; it lends support to the remarkably rapid eastward diminution proposed by A. Klein (Petermanns Geographische Mitteilungen, Quartalsheft 2, 1953, p. 98-104.)

It is just possible that a close investigation of the breadth of summits on which snow can accumulate, in relation to the firn line, might reconcile Linton's evidence for unglaciated summits with events at lower levels. Similar studies might be found to have an application in eastern North America. In any event the physics of accumulation on such summits deserves further study.

It is observed that in this note the term "firn line" refers to that prevailing on the glaciers surrounding the summits under discussion; and that each isolated snow summit may therefore possess a distinct "equilibrium-line" of its own.

Field investigations in Norway have been carried out with the aid of a grant from the Central Research Fund of the University of London, whose assistance is gratefully acknowledged.

$M S$. received I 6 November I954

\title{
THE BALANCE OF THE GRENLAND ICE SHEET
}

\author{
By Albert Bauer \\ (École Nationale d'Ingénieurs de Strasbourg)
}

\begin{abstract}
Planimetry of the is maps of scale i : I,000,000 of the World Aeronautical Chart, U.S.A.F., gives $1.726 \times 10^{6} \mathrm{~km} .2$ for the surface area of the Greenland Ice Sheet. The hypsometric curve obtained by measuring the area between contours at $1000-\mathrm{ft}$. (305 m.) intervals with a planimeter gives $2135 \mathrm{~m}$. for the mean height of the ice sheet. The normal area distribution curve of the ice sheet shows that is certainly in the "Inland Ice" type in Ahlmann's classification. The mean firn line of the ice sheet is at a height of $1390 \mathrm{~m}$. The discharge from the glaciers in the form of icebergs is estimated to be $215 \mathrm{~km} .{ }^{3}$ of water per year, and the nett balance of the ice cap is negative and about roo $\mathrm{km}^{3}$ of water per year.
\end{abstract}

RÉSumÉ. La planimétrie des ${ }_{5}$ feuilles au I : I.000.000 ème de la "World Áeronautical Chart, U.S.A.F.," donne $1,726 \times 1^{6} \mathrm{~km}^{2}$ pour la surface de l'Inlandsis du Groenland. La courbe hypsométrique déduite de la planimétrie des surfaces entre les isohypses d'intervalle 1000 pieds $(305 \mathrm{~m})$ donne $2135 \mathrm{~m}$ pour l'altitude moyenne de l'Inlandsis. La courbe normale de distribution des surfaces de l'Inlandsis montre que celui-ci entre bien dans la type "Inland Ice" de la classification d'Ahlmann. La ligne de névé moyenne de l'Inlandsis est à l'altitude I $390 \mathrm{~m}$. La décharge des glaciers sous forme d'icebergs est estimée à $215 \mathrm{~km}^{3}$ par an et le bilan de l'Inlandsis est négatif d'environ $100 \mathrm{~km}^{3}$ d'eau par an.

\section{INTRODUCTION}

Numerous studies old and new have been devoted to the Greenland Ice Sheet. Of all these that of Loewe is the most remarkable. ${ }^{1}$ It was based on a collection of all the data available in $193^{6}$ on the accumulation and ablation of the different zones of the ice sheet. The surface data were taken from the Danish map of Greenland at I : 5,000,000 on which he had traced the edge of the ice sheet.

Loewe's work now needs to be repeated using new data. We possess to-day in the I 5 sheets of the American World Aeronautical Chart ${ }^{2}$ a source of geographic information of the first order that supersedes the Danish map of Greenland. ${ }^{3}$ The American maps have the advantage that they give details of the contact between the ice sheet and the ice-free land; and they have contours at every $1000 \mathrm{ft}$. $(305 \mathrm{~m}$.). Fürther, even if Expéditions Polaires Françaises had not 
from 1948 to $195 \mathrm{I}$ produced data on accumulation and ablation capable of modifying Loewe's mean values, it is still true that numerous flights over all Greenland have given us a greater knowledge of the outflow glaciers than was possessed twenty years ago-knowledge of fundamental importance in evaluating the balance of the ice sheet.

\section{New Geographical Data}

The ${ }_{5} 5$ sheets of the American map allow us to make a new determination of the following quantities:

$$
\text { Total surface of Greenland (including islands) } \ldots \quad \ldots \quad 2.186 \times 10^{6} \mathrm{~km} .{ }^{2}
$$

Each sheet of the American map allows us to follow the limit of the ice sheet. The map (Fig. I, p. 458) shows the general shape of the entire ice sheet and of the parts in contact with it which are glacierized but which have not been taken into consideration. We have thus found:

$\begin{array}{lllll}\text { Surface area of the ice sheet } & \ldots & \ldots & \ldots & 1.7264 \times 10^{6} \mathrm{~km} .{ }^{2} \\ \text { Other glacierized areas (including islands) } & & \ldots & \ldots & 0.0762 \times 10^{6} \mathrm{~km} .{ }^{2}\end{array}$

We thus deduce the following facts:

$$
\begin{aligned}
& \frac{\text { Total glacierized surface area }}{\text { Total surface of Greenland }} \text { about } \frac{5}{6} \\
& \frac{\text { Surface area of ice sheet }}{\text { Total surface of Greenland }} \text { about } \frac{4}{5}
\end{aligned}
$$

Following the limits of the ice sheet was found to be difficult, particularly for the central part of the east side; Fig. I shows the parts neglected. However, contrary to all other authorities, we have considered that the whole of Kong Christian den IX Land, south of Scoresby Sund, and the regions to the north and south of it, ought to be included in the ice sheet. These are accumulation areas of the ice sheet, even though numerous nunataks pierce the surface, and outflow glaciers from the ice sheet traverse them.

\section{Hypsometric Curve of THe Ice SheET}

\begin{tabular}{|c|c|c|c|}
\hline \multicolumn{2}{|c|}{ Height interval } & $\begin{array}{c}\text { Surface area } \\
\left(\mathrm{km} \cdot \mathrm{r}^{2}\right)\end{array}$ & $\begin{array}{c}\text { Surface area } \\
(\%)\end{array}$ \\
\hline $0-1,000$ & o- 305 & 27,100 & $\mathrm{I} \cdot 6$ \\
\hline $1,000-2,000$ & $305-610$ & 37,200 & $2 \cdot 2$ \\
\hline $2,000-3,000$ & $610-915$ & 64,000 & 3.7 \\
\hline $3,000-4,000$ & $915-1,220$ & 93,400 & $5 \cdot 4$ \\
\hline $4,000-5,000$ & $1,220-1,525$ & 124,000 & $7 \cdot 2$ \\
\hline $5,000-6,000$ & $1,525-1,830$ & 177,400 & 10.1 \\
\hline $6,000-7,000$ & $1,830-2,135$ & 237,300 & 13.7 \\
\hline $7,000-8,000$ & $2,135-2,440$ & 290,100 & $16 \cdot 8$ \\
\hline $8,000-9,000$ & $2,440-2,745$ & 310,500 & $18 \cdot 0$ \\
\hline $9,000-10,000$ & $2,745-3,050$ & 254,200 & 14.7 \\
\hline $10,000-10,800$ & $3,050-3,300$ & 114,200 & $6 \cdot 6$ \\
\hline & & $1,726,400 \mathrm{kn}$ & $100.0 \%$ \\
\hline
\end{tabular}

We have measured the areas between the contour lines of the sheets of the American map ${ }^{2}$ with a planimeter. This gives us the following results:

The data in this table allow us to draw the hypsometric curve of the ice sheet (Fig. 2, p. 459). We have taken $3300 \mathrm{~m}$. as the maximum height, a value that was measured once barometrically (uncorrected) at lat. $72^{\circ} 00^{\prime}$ N., long. $37^{\circ} 30^{\prime} \mathrm{W}$. by Expéditions Polaires Françaises in 195I. This figure may therefore be somewhat too large; if we take account of this, we see that our hypsometric curve is more regular than that of Loewe. ${ }^{1}$ Further, between the maximum altitude and 7000 feet (2135 m.) it is practically linear; it cannot therefore be likened to a parabola as Meinardus ${ }^{4}$ assumed.

The curve allows us to determine the mean height of the ice sheet; it is $7000 \mathrm{ft}$. or $2135 \mathrm{~m}$., as compared to the $2100 \mathrm{ft}$. of Loewe. ${ }^{1}$ 


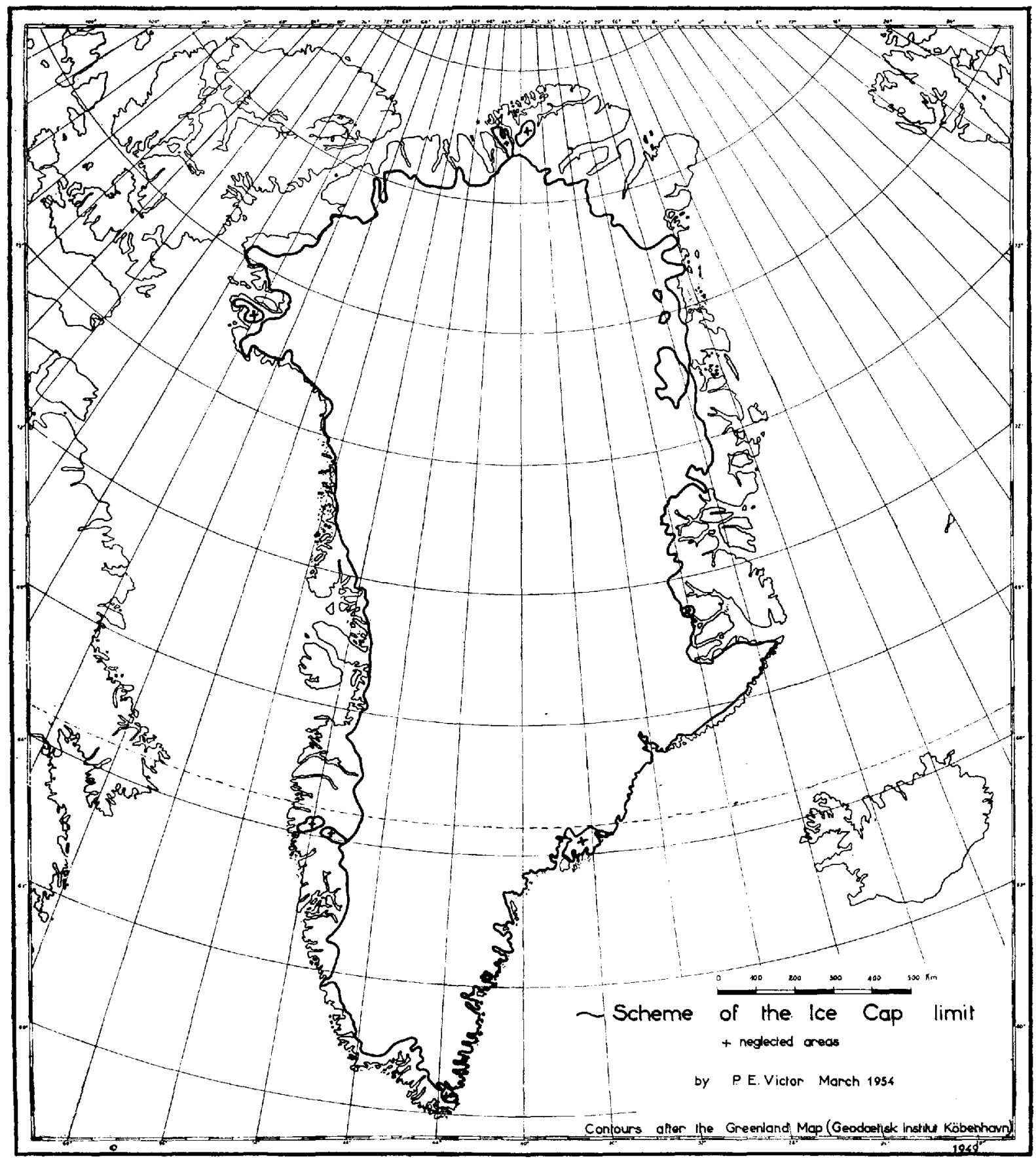

Fig. I. Limits of the Greenland Ice Sheet 


\section{Normal Area Distribution Curve}

We have divided the altitude variation of the ice sheet into ten parts, and have read off from the hypsometric curve the percentages of the area between these contours. The accuracy of this determination is high, as the rooo-ft. contours are close to these at tenths of the total height.

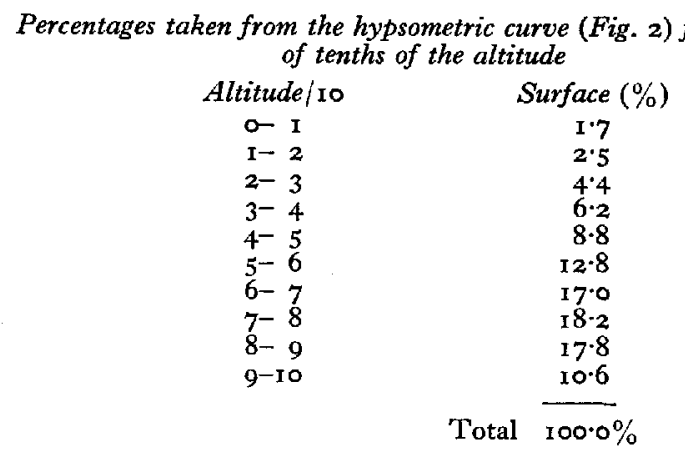

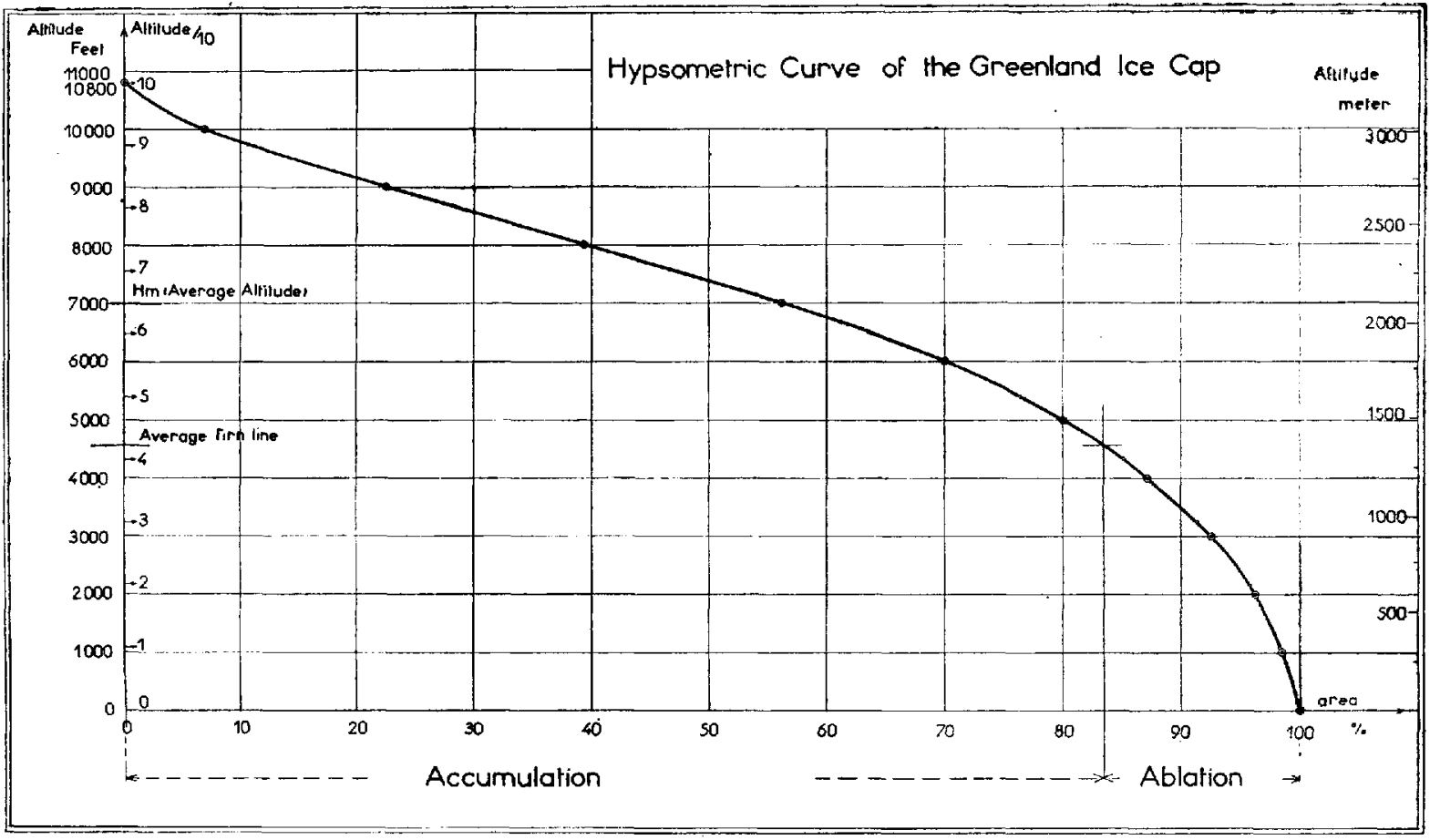

Fig. 2

The percentages of total area have been plotted against the altitude in units of total height/ro in Fig. 3 (p. 460) taking care to use a scale in which altitude/Io and 6 per cent are of the same magnitude, and we have thus obtained the normal area distribution curve for the ice sheet.

This method of procedure is that which allowed Ahlmann ${ }^{5}$ to obtain characteristic curves for the different glacier types, whatever their configuration. These "normal curves" allowed him to establish a new classification of glaciers. With the normal curve which we have obtained the ice sheet fits well into the AhImann classification, being of the type "Inland Ice and Glacier Cap." 
There are several other classifications of glaciers, but the Greenland Ice Sheet never quite fits into them. To quote but one example, it only fits imperfectly into the classification of Wright and Priestley. 6 We cannot thus but commend the Ahlmann classification which is the one into which, for the first time, the Greenland Ice Sheet enters.

\section{The Firn Line of the ICE SheEt}

Using all the literature cited by Loewe ${ }^{1}$ and also the observations of Expéditions Polaires Françaises, ${ }^{7}$ we have adopted a firn line for each sheet of the American map.

No. American map sheet

$\begin{aligned} 8 & \text { Robeson Channel } \\ 9 & \text { Independence Fjord } \\ \text { I8 } & \text { Germania Land } \\ \text { 19 } & \text { Humboldt Glacier } \\ 20 & \text { Smith Sound } \\ 38 & \text { Devil's Thumb .. } \\ 39 & \text { Greenland Ice Cap } \\ 40 & \text { Clavering Island } \\ 55 & \text { Scoresby Sound . . } \\ 56 & \text { Prince of Wales Mts. } \\ 57 & \text { Disko Bay a } \\ 85 & \text { Fiske Fjord .. } \\ 86 & \text { Cape Gustav Holm } \\ 109 & \text { Cape Cort Adelaer } \\ \text { 146 } & \text { Cape Farvel .. }\end{aligned}$

The corresponding areas are:

Height of the firn line for the sheet

\begin{tabular}{cc} 
(feet) & (metres) \\
3000 & 915 \\
4000 & 1220 \\
4000 & 1220 \\
4000 & 1220 \\
4000 & 1220 \\
4000 & 1220 \\
4000 & 1220 \\
5000 & 1525 \\
6000 & 1830 \\
5000 & 1525 \\
5000 & 1525 \\
5000 & 1525 \\
5000 & 1525 \\
6000 & 1830 \\
\hline
\end{tabular}

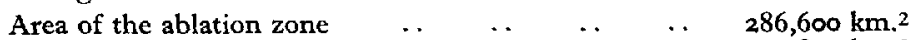

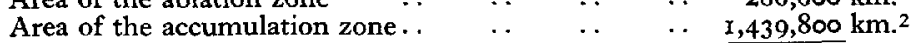

Total (area of the ice sheet) $\quad$. $\quad \ldots \quad$. $\quad 1,726,400 \mathrm{~km}, 2$

We deduce from this that:

$$
\begin{array}{cccccr}
\text { Ablation area } & . & \ldots & . & . & 16.5 \% \\
\begin{array}{c}
\text { Accumulation area } \\
\text { Total }
\end{array} & . & . & . & . & 83.5 \% \\
\hline & . & . . & . . & . . & 100.0 \%
\end{array}
$$

These figures allow us to determine the mean firn line of the ice sheet, using the hypsometric curve (Fig. 2). Its altitude is $4560 \mathrm{ft}$. ( $1390 \mathrm{~m}$.).

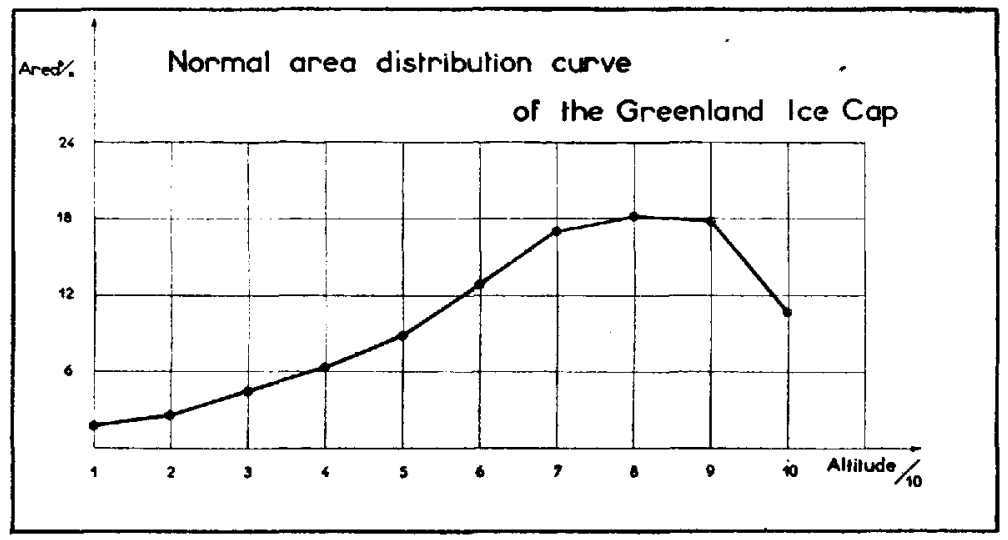

Fig. 3

\section{The Discharge from Glaciers in the Form of Icebergs}

To evaluate the discharge from glaciers in the form of icebergs, we have adopted the following procedure. Starting with the existing literature on the different glaciers which flow from the ice 


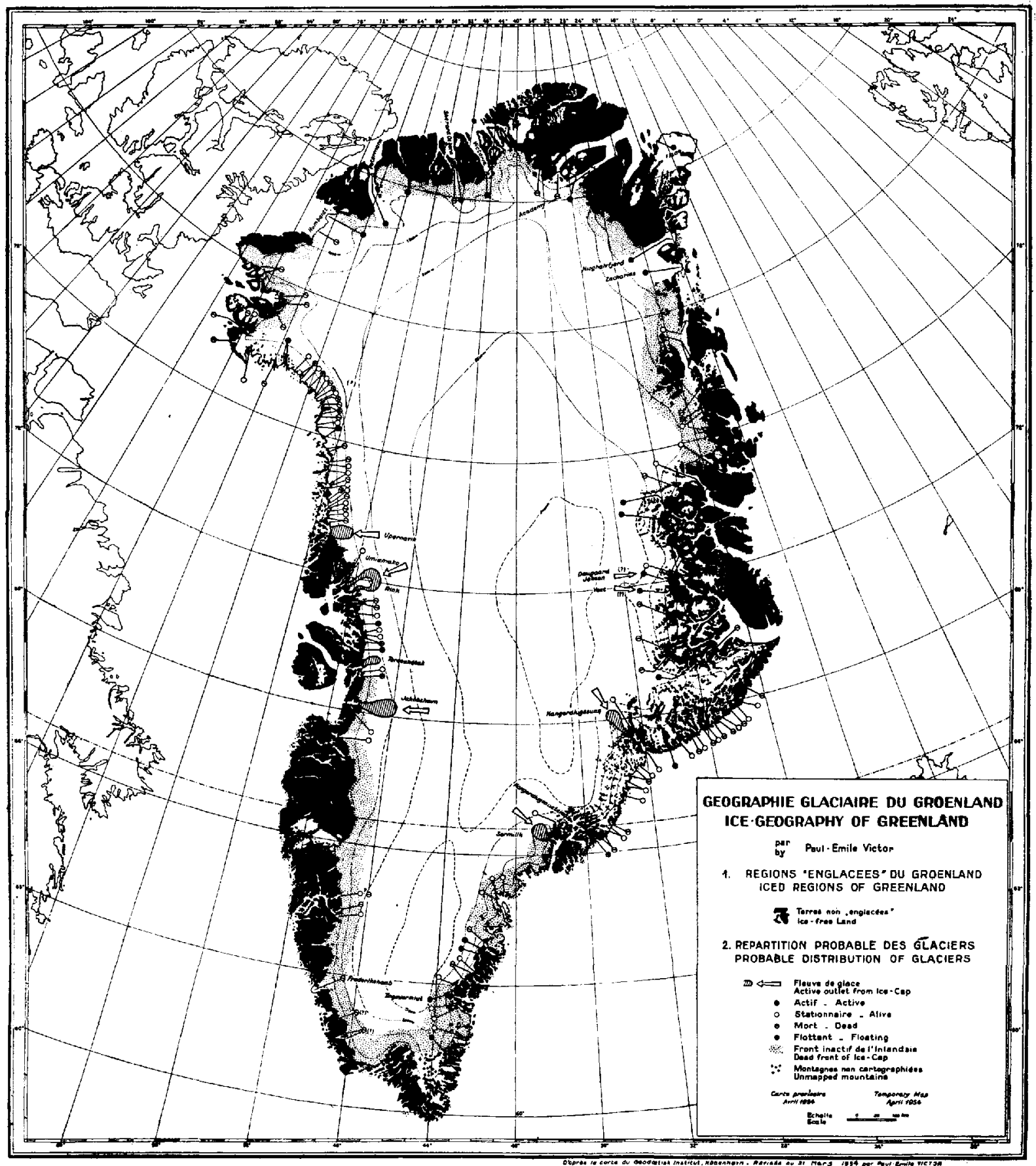

Fig. 4. Glacier geography of Greenland (after P. E. Victor) 
sheet, with the American map, ${ }^{2}$ the maps at $\mathrm{I}: 250,000$ of the Danish Geodetic Institute ${ }^{8}$ and with the map of Paul Emile Victor (Fig. 4, p. 46r), we have made a list of all the Greenland glaciers draining ice from the ice sheet. For those glaciers for which neither speed nor outflow are known, we have determined the length of the front, and where possible the thickness of the front, from the depth of the fjord near the front, following Boyd..$^{9}$ From the speeds measured on various glaciers such as Eqip Sermia, ${ }^{10}$ we have taken speeds of 3 to $10 \mathrm{~m}$. in 24 hours for the active glaciers, less than $3 \mathrm{~m}$. in 24 hours for stationary glaciers, and $30 \mathrm{~m}$. per year for dead glaciers from our measurements on Nunap Kigdlinga. ${ }^{11}$ These latter velocities have also been taken for the parts of the ice sheet discharging into the sea, as occurs in Melville Bay and south of Angmagssalik.

This method gave us the following results:

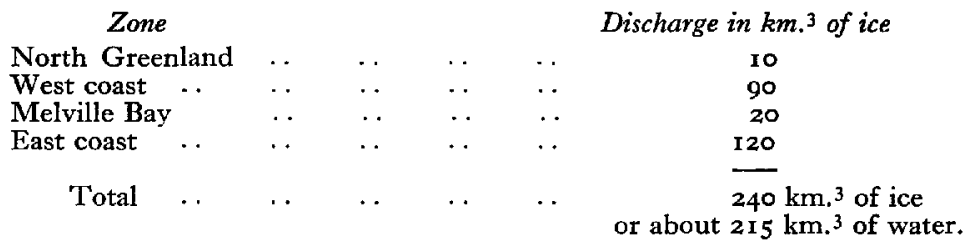

As the edge of the ice sheet (Fig. I) in the east of Greenland extends to the neighbourhood of the coast, we had to take account of almost all the coastal glaciers. It is worth remarking that our figures show that the discharge from glaciers in the form of icebergs is practically the same on the east coast as on the west, contrary to general belief.

\section{Balance of the Ice Sheet}

We have adopted Loewe's figures for the mean ablation ( $\mathrm{I} \cdot \mathrm{I} \mathrm{m}$. of water) and for the mean accumulation $(0.31 \mathrm{~m}$. of water) for the whole of the ice sheet. We thus find:

$$
\begin{aligned}
& \text { Accumulation } \quad \ldots \quad \ldots \quad \ldots \quad \ldots \quad \ldots \quad \ldots 446 \mathrm{~km}^{3} \text { of water }
\end{aligned}
$$

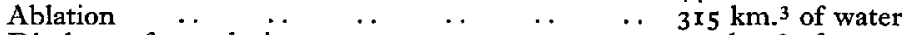

$$
\begin{aligned}
& \text { Discharge from glaciers } \quad \ldots \quad \quad \ldots \quad \quad \ldots \quad \ldots \quad 215 \mathrm{~km} .{ }^{3} \text { of water }
\end{aligned}
$$

giving a deficit of about $100 \mathrm{~km} \cdot{ }^{3}$ of water per annum.

Loewe ${ }^{1}$ came to the conclusion that the ice sheet was stationary; our value for the discharge from glaciers $\left(215 \mathrm{~km} .{ }^{3}\right)$ is larger than his $\left(120 \mathrm{~km} .{ }^{3}\right)$, which is the reason for our negative balance.

It must be remembered that all these figures are known only with very low accuracy, as a small error in the mean ablation and accumulation is multiplied by a very large factor.

One should add that because the accumulation area $(83.5$ per cent) is much larger than the ablation area ( 16.5 per cent), the glaciers of the ice sheet must be very sensitive to fluctuations in accumulation.

MS. received Io May 1954

\section{R E F E R E N CES}

I. Loewe, F. Höhenverhältnisse und Massenhaushalt des grönländischen Inlandeises. Gerlands Beiträge zur Geophysik, Bd. 46 , Ht. 3 , 1936, p. $317-30$; Bd. 48 , Ht. I, I936, p. 86-89.

2. American map, World Aeronautical Chart, I: 1,000,000, North Polar Area, Nos. 8, 9, 18, 19, 20, 38, 39, 40, 55, 56, $57,85,86$, I09, I 46, U.S.A.F., Washington, 1951 .

3. Danish map, Grönland, I : 5,000,000. Geodætisk Institut, Köbenhavn, 1950.

4. Meinardus, W. Die Hypsographischen Kurven Grönlands und der Antarktis und die Normalform der Inlandeisoberfläche. Petermanns Geographische Mitteilungen, Jahrg. 72, Ht. 5-6, 1926, p. 97-105.

5. Ahlmann, H. W:son. Glaciological Research on the North Atlantic coasts. R.G.S. research series, No. 1. London, Royal Geographical Society, 1948.

6. Wright, C. S., and Priestley, R. E. Glaciology, British (Terra Nova) Antarctic Expedition I910-13. London, Harrison and Sons, 1922.

7. Expéditions Polaires Françaises. Rapport Préliminaire de la Campagne au Groenland (I949), Série Scientifique ıo.

8. Danish maps. Grönland, I:250,000 Nos 68 V.2, 69 V.2, 70 V.2, 7I V.2, 72 V.2, 70 O.. , 70 Ö.2, 7r. Ö.r, 71 Ö.2, $72 \ddot{0} .3,73$ O..2, 73 Ö.3, $73 \ddot{O}_{4}, 74$ Ö.2, 74 Ö.3, 75 O..2, Geodxtisk Institut, Köbenhavn, $1936-37$.

9. Boyd, L. A. The coast of North East Greenland. American Geographical Society, Special Publication No. $30, \mathrm{x} 948$.

10. Bauer, A. Glaciologie-Groenland, Vol. I: Le Glacier de l'Eqe. In the press.

I I. Expéditions Polaires Françaises. Rapport Préliminaire de la Campagne Préparatoire au Groenland (I948), Série Scientifique 5 bis, $7 \mathrm{p}$. 